\title{
Probabilistic risk assessment of the environmental impacts of pesticides in the Crocodile (west) Marico catchment, North-West Province
}

\author{
TM Ansara-Ross ${ }^{1 *}$, V Wepener ${ }^{1}$, PJ Van den Brink ${ }^{2,3}$ and MJ Ross ${ }^{1}$ \\ ${ }^{1}$ Centre for Aquatic Research, Department of Zoology, University of Johannesburg, Auckland Park, PO Box 524, \\ Johannesburg 2006, South Africa \\ ${ }^{2}$ Wageningen University, Department of Aquatic Ecology and Water Quality Management, Wageningen University \\ and Research centre, PO Box 47, 6700 AA Wageningen, The Netherlands \\ ${ }^{3}$ Alterra, Wageningen University and Research centre, PO Box 47, 6700 AA Wageningen, The Netherlands
}

\begin{abstract}
External agricultural inputs, such as pesticides, may pose risks to aquatic ecosystems and affect aquatic populations, communities and ecosystems. To predict these risks, a tiered approach was followed, incorporating both the PRIMET and PERPEST models. The first-tier PRIMET model is designed to yield a relatively worst-case risk assessment requiring a minimum of input data, after which the effects of the risks can be refined using a higher tier PERPEST model. The risk assessment initially depends on data supplied from local landowners, pesticide characteristic, application scheme and physical scenario of the environment under question. Preliminary results are presented, together with ecotoxicological data on several frequently-used pesticides in a section of the Crocodile (west) Marico Water Management Area (WMA) in South Africa. This area is historically known to have a high pesticide usage, with deltamethrin, aldicarb, parathion, cypermethrin and dichlorvos being the main pesticides used. Deltamethrin was indicated as having the highest probability of risks to aquatic organisms occurring in the study area. Cypermethrin, parathion, dichlorvos, carbaryl, bromoxynil, linuron, methomyl and aldicarb were all indicated as having possible risks (ETR 1-100) to the aquatic environment. Pesticides posing no risk included fenamiphos, abamectin, pendimethalin, captan, endosulfan, alachlor, bentazone and cyromazine $(\mathrm{ETR}<1)$. The pesticides posing a possible risk to the aquatic ecosystem were evaluated further to determine their effects on 8 grouped endpoints using the PERPEST effect model. Deltamethrin and cypermethrin were again noted as posing the greatest risk and clear effects were eminent for aquatic insects and macro-crustaceans, followed by micro-crustaceans and rotifers. High percentages of clear effects on insects were also observed for carbaryl, parathion and dichlorvos. Linuron was indicated as having minimal clear effects on community metabolism, macrophytes and phytoplankton classes, while lesser clear effects of bromoxynil occurred on periphyton communities. Application of both the lower-tier PRIMET and higher-tier PERPEST models showed similar trends in that they both ranked the top 5 pesticides in the same order of risk. This approach offers a significant improvement over the presently-used simulation models or use of safety factors. It is therefore especially useful in developing countries such as South Africa, where pesticide environmental risk information is scarce. Although these models were effectively used in this study, it still has to be validated further under South African conditions
\end{abstract}

Keywords: risk-assessment model, pesticides, aquatic ecosystem

\section{Introduction}

Agriculture forms an important component of South Africa's economy, with extrinsic inputs, like pesticides and fertilisers, helping to ensure a reliable and high agricultural yield. The use of such agrochemicals has benefited the quality of human health in terms of food security and quality. Extensive and improper application of these pesticides, however, may pose risks to aquatic ecosystems and consequently affect non-target populations, communities and ecosystems. A large number of different pesticides are currently available to agriculture, most of which are applied frequently. For this reason, it is important to be able to assess which of these chemicals pose the greatest risks to the environment.

As far as could be ascertained, no risk-assessment studies using probabilistic models have been undertaken within South Africa to determine the effects of pesticides to the freshwater aquatic environment. The studies that have been undertaken

\footnotetext{
* To whom all correspondence should be addressed.

e-mail: tahla@global.co.za
}

(e.g. Schulz (2001) and Bollmohr et al. (2007)) focus primarily on pesticide exposures and effects in estuaries and rivers within the Western Cape. These authors, however, do not report on the application of a probabilistic modelling approach for pesticide risk assessment for South Africa.

Present techniques used in assessing the ecological fate and effect of pesticides under realistic field conditions involve a large number of parameters to be measured. These can therefore incorporate intricate and detailed simulation models such as ecological, population or food-web models (e.g. Koelmans et al., 2001; Traas et al., 1998; Van den Brink et al., 2007). These risk-assessment models often have drawbacks, which include a lack of transparency, a high degree of complexity that can cause compounding errors through erroneous primary data, and expensive implementation thereof (Van den Brink et al., 2006; Van der Werf, 1996). The intricate input data required are also unavailable for many pesticides. These models also very often focus only on certain aspects of risk assessment and therefore have limited application. These aspects pose restrictions, especially for developing countries that lack the resources (London et al., 2005). 
The development of the PRIMET and PERPEST models was aimed at surpassing these limitations by being centred on delivering results of increased scope of application, with limited input data being required to evaluate the risks of pesticides to the environment. This allows for people without specialist training in the scientific field to utilise the models for monitoring as well as for management applications (e.g. farmers).

The risks of pesticides to the environment are evaluated by taking into account factors associated with both exposure (by calculating the predicted concentrations) and effect assessments (by determining safe concentrations based on laboratory toxicity data and the use of assessment factors) of the compound in question and incorporating the quantity used and doses applied to a defined scenario. Application rate is known to be an important explanatory variable determining the concentration of the pesticide in the environment (Van der Werf, 1996; Tesfamichael and Kaluarachchi, 2006) and needs to be taken into consideration when using risk-assessment models. This aspect is taken into consideration for these models.

The PRIMET Decision Support System (Pesticide Risks in the Tropics to Man, Environment and Trade, Van den Brink et al., 2005) can be applied to estimate the lower-tier risks of pesticide application on aquatic and terrestrial ecosystems, groundwater as well as human health aspects - via dietary exposure by consuming vegetables, fish or macrophytes. In this preliminary risk assessment only entry via spray drift was taken into consideration. This model uses defined scenarios and is applicable to a warmer environment, specifically in developing countries (such as South Africa) as it includes a temperature-dependent assessment of the exposure concentration (this is included in the degradation and volatilisation rate parameters such as half-life, saturated vapour pressure and solubility). The PRIMET version 1.0 model has already been used in developing south-east Asian countries (including Thailand and Sri Lanka) and is designed to yield a relatively worst-case risk assessment, requiring a minimum of input data (Van den Brink et al., 2003; Satapornvanit et al., 2004). The model, however, needs to be appropriately adapted to enable it to be applied and validated under South African conditions.

The input variables needed to feed the aquatic component of the PRIMET model were pesticide properties, site-specific conditions and characteristics of the pesticide application as indicated by the standard agronomic practices used by farmers in the area. The output of this model is expressed in an Exposure Toxicity Ratio (ETR). This is defined as the risk ratio between the environmental concentration (PEC) and the estimated safe concentration (PNEC). The value of an ETR is seen as an estimation of the potential risks posed by a given agrochemical for a specific scenario (Linders and Luttik, 1995). This is represented in the three classes of 'no risk', 'possible risk' or 'definite risk'. If an ETR score is less than one, the risk is acceptable and no further risk assessment would be required. If larger than 1 but less than 100 , a risk may be present. If the ETR is larger than 100, a definite risk (based on the worst-case scenario) is assumed. If a possible or definite risk is indicated in this lower tier assessment, higher tier models such as the fate models TOXSWA (TOXic substances in Surface Waters, Beltman and Adriaanse, 1999) and PEARL (Pesticide Emission Assessment of Regional and Local Scales, Tiktak et al., 2000) and the effect models PERPEST (Predicting the Ecological Risks of PESTicides, Van den Brink et al., 2002) and SSD (Species Sensitivity Distributions, Posthuma et al., 2002), can be applied to establish a more realistic characterisation of risk.

The SSD concept as an effect assessment was not covered in this paper. The authors feel that the PERPEST model is better suited for field-relevant data as it is based on the results of semi- field experiments and includes actual case scenarios, whilst the SSD concept is based on laboratory data only.

The PERPEST model (Van den Brink et al., 2002; Van Nes and Van den Brink, 2003; Van den Brink et al., 2006) predicts the toxic effects of a particular concentration of a pesticide on grouped endpoints. The PERPEST expert model is based on a case-based reasoning (CBR) approach. This is a technique that solves new problems by using past experience. For developing the model, empirical data were extracted from published literature describing the results from mesocosm and microcosm experiments for freshwater model ecosystem studies with pesticides (Brock et al., $2000 \mathrm{a} ; 2000 \mathrm{~b}$ ) and were collated within a database. When evaluating the effects of insecticides, the results of these experiments are assigned to 1 of 8 endpoint categories: algae and macrophytes; community metabolism; fish; insects; macro-crustaceans; microcrustaceans; other invertebrates and rotifers. For herbicides, the 8 effect groupings are as follows: macrophytes; periphyton; phytoplankton; zooplankton; community metabolism; fish and tadpoles; molluscs and macro-crustaceans and insects (Van den Brink et al., 2006). Except for community metabolism, all other effect categories represent structural endpoints, while the former represents a functional response. When the effect of a particular concentration of a particular pesticide has to be predicted, the PERPEST model searches for analogous situations in the database based on relevant (toxicity) characteristics of the compound, exposure concentration and type of ecosystem to be evaluated (Van den Brink et al., 2006). This allows the model to use information on other pesticides when predicting effects of a particular pesticide. The parameters for the prediction can be optimised by using a controlled random search procedure (Van den Brink et al., 2002). The PERPEST model results in a prediction showing the probability of no, slight or clear classes of effects on the various grouped endpoints at a specific concentration of a pesticide. All grouped endpoints are simultaneously selected from the PERPEST model for the insecticides and herbicides indicating possible or definite risks in the PRIMET model. This provides a more realistic estimation of effects. The PERPEST model therefore overcomes the contentious issue surrounding the use of singlespecies toxicity tests for predictions in risk assessment at higher levels (Levitan et al., 1995) as it uses information gathered at the ecosystem level.

The PRIMET model therefore calculates whether a risk of a certain pesticide is eminent, whereas the PERPEST model qualifies and defines the risk. The PERPEST model refines the outcome of the risk as determined from the PRIMET model. For a more detailed description on the equations and calculations used for the PRIMET and PERPEST models, refer to Van den Brink et al. (2005) and Van Nes and Van den Brink (2003), respectively.

Preliminary results are presented, together with ecotoxicological data on several frequently used pesticides in a section of the upper reach of the Crocodile (west) Marico Water Management Area (WMA) in South Africa. This area is historically known to have a high pesticide usage, with aldicarb, cypermethrin, deltamethrin, dichlorvos, endosulfan and parathion being the main pesticides used within the area as indicated by the pesticide consultants within the area (Van der Merwe, 2005) The area is intensively irrigated with the source of water being from a network of canals entering and leaving the Crocodile and Magalies Rivers. In this study, it is demonstrated how the models can be implemented to assess the potential risks of agricultural pesticides in South Africa, using only baseline data in an area known to have a high pesticide usage and where little information is available.

This paper addresses two research questions: 


\begin{tabular}{|c|c|c|c|c|c|c|c|c|c|}
\hline \multicolumn{10}{|c|}{$\begin{array}{r}\text { TABLE } 1 \\
\text { Pesticides used in the study area with their type of } u\end{array}$} \\
\hline $\begin{array}{l}\text { Active } \\
\text { ingredient }\end{array}$ & Pesticide type & $\begin{array}{l}\text { Molecu- } \\
\text { lar mass }\end{array}$ & $\begin{array}{c}\text { Saturated } \\
\text { vapour } \\
\text { pressure } \\
(\mathrm{Pa})\end{array}$ & $\begin{array}{c}\text { Tem- } \\
\text { perature } \\
\text { saturated } \\
\text { vapour } \\
\text { pressure } \\
\left({ }^{\circ} \mathrm{C}\right)\end{array}$ & $\begin{array}{l}\text { Solubility } \\
\left(g / \mathrm{m}^{3}\right)\end{array}$ & $\begin{array}{c}\text { Tem- } \\
\text { perature } \\
\text { solubil- } \\
\text { ity } \\
\left({ }^{\circ} \mathrm{C}\right)\end{array}$ & \begin{tabular}{|c|}
$\mathrm{DT}_{50} \mathrm{I}$ \\
half-life- \\
water \\
(days)
\end{tabular} & $\begin{array}{l}\mathrm{DT}_{50} 0^{-} \\
\text {sedi- } \\
\text { ment } \\
\text { (days) }\end{array}$ & $\begin{array}{l}\mathrm{K}_{\mathrm{om}} \\
(\ell / \mathrm{kg})\end{array}$ \\
\hline Abamectin & Insecticide, Acaricide & 873.1 & $2.00 \mathrm{E}-07$ & 22.5 & 7.00E-03 & 20 & 28 & 28 & 2842 \\
\hline Alachlor & Herbicide & 269.8 & $1.90 \mathrm{E}-03$ & 25 & 242.00 & 22 & 149 & 22 & 117 \\
\hline Aldicarb & $\begin{array}{l}\text { Insecticide, Acaricide, } \\
\text { Nematicide }\end{array}$ & 190.3 & 0.013 & 20 & $4.93 \mathrm{E}-03$ & 20 & 10 & 23 & 17.4 \\
\hline Betazone & Herbicide & 269.8 & $0.46 \mathrm{E}-03$ & 20 & 0.05 & 20 & 2 & 14 & 20.3 \\
\hline Bromoxynil & Herbicide & 276.9 & $0.64 \mathrm{E}-03$ & 20 & $0.13 \mathrm{E}-03$ & 25 & 10 & 10 & 58 \\
\hline Captan & Fungicide & 300.6 & $1.10 \mathrm{E}-05$ & 25 & 5.10 & 22.5 & 1 & 1 & 5 \\
\hline Carbaryl & Insecticide, PGR & 201.2 & $0.041 \mathrm{E}-03$ & 23.5 & 120.00 & 20 & 14 & 14 & 34 \\
\hline Cypermethrin & Insecticide & 416.3 & $0.19 \mathrm{E}-06$ & 20 & $4.00 \mathrm{E}-03$ & 20 & 14 & 36 & 2137 \\
\hline Cyromazine & Insecticide & 166.2 & $0.45 \mathrm{E}-06$ & 25 & $0.01 \mathrm{E}-03$ & 22 & 28 & 63 & 438.5 \\
\hline Deltamethrin & Insecticide & 505.2 & $1.24 \mathrm{E}-08$ & 25 & $0.20 \mathrm{E}-03$ & 25 & 2 & 25 & 476 \\
\hline Dichlorvos & Insecticide, Acaricide & 221.0 & 2.666 & 25 & $0.02 \mathrm{E} 06$ & 25 & 0.1 & 2 & 87 \\
\hline Endosulfan & Insecticide, Acaricide & 406.9 & $2.30 \mathrm{E}-05$ & 25 & 0.32 & 22 & 36 & 50 & 7.087E07 \\
\hline Fenamiphos & Insecticide, Nematicide & 303.4 & $0.12 \mathrm{E}-03$ & 20 & $0.70 \mathrm{E}-03$ & 20 & 0.4 & 50 & 58 \\
\hline Linuron & Herbicide & 249.1 & $2.00 \mathrm{E}-03$ & 24 & $0.08 \mathrm{E}-03$ & 25 & 262 & 60 & 232 \\
\hline Methomyl & Insecticide, Acaricide & 162.2 & $0.72 \mathrm{E}-03$ & 25 & $5.80 \mathrm{E} 04$ & 25 & 8 & 8 & 12 \\
\hline Parathion & Insecticide, Acaricide & 291.3 & $0.89 \mathrm{E}-03$ & 20 & 24.00 & 20 & 1.5 & 49 & 1764 \\
\hline Pendimethalin & Herbicide & 281.3 & $4.00 \mathrm{E}-03$ & 25 & 0.28 & 25 & 28 & 90 & $2.4 \mathrm{E} 04$ \\
\hline
\end{tabular}

- Can this first-tier model (PRIMET) be used efficiently to estimate environmental risks associated with pesticides for the study area?

- What will the predicted effects of selected pesticides be on non-target groups of aquatic organisms using the higher-tier PERPEST model at concentrations predicted by the PRIMET model?

\section{Materials and methods}

\section{General approach}

The general approach of methodologies followed for this study involved the first-tier preliminary estimation of the risks posed by each pesticide to the aquatic ecosystem with the application of the PRIMET model. This was used as a screening tool for this lowertier risk assessment. The PEC values for each pesticide showing possible or definite risks were further evaluated by the higher-tier PERPEST effect model to determine the effects on aquatic organisms at these concentrations.

The exposure component of the PRIMET Model (understanding of the dispersion of a chemical in the environment) involved the calculation of a Predicted Environmental Concentration (PEC) in the watercourse, e.g. adjacent to agricultural activities. This PEC is based on a worst-case scenario representative for local conditions. Acute risks were the focus of this study. The PEC was represented by the peak concentration and not by a time-weighted average exposure concentration following Van den Brink et al. (2005). This PEC was then related to the effect component (expected 'safe' concentration or a Predicted No-Effect Concentration (PNEC)) based on toxicity data for selected standard test species from different trophic levels, namely algae (primary producers), Daphnia (invertebrates) and fish (vertebrates). This PNEC also incorporated an assessment factor, calculated by multiplying the toxicity value of the most sensitive standard test species by an assessment factor (100 for fish and Daphnia and 10 for algae and macrophytes). This was done to extrapolate from the $\mathrm{EC}_{50}$ level to a concentration at which no effects on the organisms were expected. This assessment factor was also needed to account for interspecies variation and to protect indigenous aquatic populations (EU, 1997; Van den Brink et al., 2005). The PNEC that was used in the PRIMET model is regarded as conservative as the assessment factors were relatively large to counteract the lack of ecological realism. This was in accordance with Brock et al. (2000a; 2000b; 2006).

The PRIMET model was used to calculate the first-tier PEC and PNEC concentrations, and the resulting PEC value was evaluated further for the effects (PNEC) on 8 aquatic endpoints using the higher-tier PERPEST effect model (Van den Brink et al., 2002) as described above.

\section{Parameters governing the fate of pesticides applicable to the model}

\section{Pesticide characteristics}

The pesticide characteristics that were required as input data for the aquatic component of the PRIMET model are given in Table 1. Only active ingredients used in large quantities in the study area were selected. The input variables for most of these pesticides were readily available due to their widespread usage. Chemical properties were obtained from various open scientific literature sources, if not already given in the PRIMET database. All relevant $\mathrm{EC}_{50}$ values available up to and including 2006 on each of these groups were extracted from databases such as the U.S. EPA AQUIRE (2006); PAN (2006); EXTOXNET (2004) toxicity databases, the Pesticide Manual (Tomlin, 2000) and peerreviewed literature. The selected toxicity data were taken from acute static tests resulting in $\mathrm{EC}_{50}$ values for freshwater invertebrates $(48 \mathrm{~h})$, vertebrates $(96 \mathrm{~h})$ and primary producers $(72 \mathrm{~h}$ and 96 h). Effective concentration (EC) and lethal concentration (LC) were treated similarly, for reasons given in Solomon et al. (2001). Where more than one value was obtained for the same pesticide- 


\begin{tabular}{|c|c|c|c|}
\hline \multicolumn{4}{|c|}{$\begin{array}{c}\text { TABLE } 2 \\
\text { Acute toxicity data used in the PRIMET model for } \\
\text { standard test organisms for each taxonomic group, } \\
\text { namely vertebrates ( } 96 \mathrm{~h}) \text {, invertebrates }(48 \mathrm{~h}) \text { and } \\
\text { primary producers }(96 \mathrm{~h})\end{array}$} \\
\hline $\begin{array}{l}\text { Active ingre- } \\
\text { dient }\end{array}$ & $\begin{array}{l}\text { Vertebrates } \\
\text { L(E)C } \\
(\mu \mathrm{g} / \ell)^{\mathrm{a}}\end{array}$ & $\begin{array}{c}\text { Invertebrates } \\
\mathrm{L}(\mathrm{E}) \mathrm{C}_{50} \\
(\mu \mathrm{g} / \ell)^{\mathrm{b}}\end{array}$ & $\begin{array}{l}\text { Primary } \\
\text { producers } \\
\mathrm{L}(\mathrm{E}) \mathrm{C}_{50} \\
(\mu \mathrm{g} / \ell)^{\mathrm{a}}\end{array}$ \\
\hline Abamectin & $31.46 \mathrm{E} 03$ & 1.5 & $0.1 \mathrm{E} 06$ \\
\hline Alachlor & $5.69 \mathrm{E} 03$ & $53.06 \mathrm{E} 03$ & 900.5 \\
\hline Aldicarb & 954.8 & $1.79 \mathrm{E} 03$ & nd \\
\hline Betazone & $436 \mathrm{E} 03$ & 229.7E03 & 279E03 \\
\hline Bromoxynil & 11.77E03 & 11 & 7.14E03 \\
\hline Captan & 126.5 & 1.761E06 & 944.4 \\
\hline Carbaryl & $4.051 \mathrm{E} 03$ & 53.92 & 1.272E03 \\
\hline Cypermethrin & 28.07 & 0.36 & nd \\
\hline Cyromazine & 89.73E03 & $97.8 \mathrm{E} 03$ & nd \\
\hline Deltamethrin & 31.24 & 0.05 & 9.1E06 \\
\hline Dichlorvos & $1.93 \mathrm{E} 03$ & 3.25 & $52.8 \mathrm{E} 06$ \\
\hline Endosulfan & 3.92 & 3.89 & 232.2 \\
\hline Fenamiphos & 661.4 & 755 & nd \\
\hline Linuron & $7.91 \mathrm{E} 03$ & 310 & 7 \\
\hline Methomyl & $1.27 \mathrm{E} 03$ & 372.7 & nd \\
\hline Parathion & $1.07 \mathrm{E} 03$ & 2.99 & 500 \\
\hline Pendimethalin & $3.60 \mathrm{E} 03$ & 280 & 72.44E03 \\
\hline \multicolumn{4}{|c|}{$\begin{array}{l}{ }^{a} \text { Aquatic toxicity } L(E) C 50: 96 \text { h exposure time } \\
{ }^{b} \text { Aquatic toxicity } L(E) C 50: 48 \text { exposure time } \\
\text { nd: no data available }\end{array}$} \\
\hline
\end{tabular}

species combination, the geometric mean toxicity value was used to represent that taxonomic group.

\section{Physical scenario of the aquatic environment}

The physical scenario was chosen in such a way that it was representative of the aquatic (surface water) water bodies of the research area. For this, 3 sites were selected along the canal system and assessed during 2 field surveys in May and October 2005. The 2 surveys were regarded as being representative of high- and low-flow conditions within the irrigation canals. Field measurements were taken on the geometry of the water course at all 3 sites, i.e. the bottom width of water body (b), depth of water body (h), length of water body (L) and side slope ( $\left.\mathrm{s}_{1}\right)$, of the canal. All measurements were taken with a tape measure and presented in meters. The average water flow velocity (v) was determined using an OTT flow meter fitted with a No. 3 calibration flow propeller. Triplicate water samples $(250 \mathrm{~m} \ell)$ were collected during each survey from the 3 sites and the temperature, mass fraction organic matter in suspended solids $\left(\mathrm{m}_{\mathrm{om}}\right)$ and mass concentration of suspended solids (SS) in water were measured using the filtration and dying techniques described by Wepener and Vermeulen (2005). The temperature $(\mathrm{T})$ was recorded on site using a hand-held thermometer.

\section{Application scheme}

The required input data for PRIMET regarding application scheme (i.e. the number of applications (n), the individual application dosage $(\mathrm{M})$ and the frequency between applications $(\Delta \mathrm{t})$ ) were obtained directly from the farmers, experts and pesticide consultants within the area. The percentage spray drift (\% drift) was predicted using the IMAG Drift Calculator v1.1 (Holterman

\begin{tabular}{|c|c|c|c|}
\hline \multicolumn{4}{|c|}{$\begin{array}{c}\text { TABLE } 3 \\
\text { Physical scenario parameter values of the water } \\
\text { body defined to calculate } 1^{\text {st }} \text { tier ETR values using } \\
\text { PRIMET }\end{array}$} \\
\hline Parameter & $\mathbf{N}$ & Mean & SD \\
\hline Bottom width of water body $(\mathrm{m})$ & 3 & 6.1 & 1.49 \\
\hline Depth of water body (m) & 3 & 1.5 & 0.5 \\
\hline Length of water body $(\mathrm{m} /)$ & 1 & $55^{\mathrm{a}}$ & \\
\hline $\begin{array}{l}\text { Mass fraction organic matter in } \\
\text { suspended solids }(\mathrm{g} / \mathrm{g})\end{array}$ & 3 & 0.34 & 0.202 \\
\hline $\begin{array}{l}\text { Mass concentration of sus- } \\
\text { pended solids in water }(\mathrm{kg} / \ell)\end{array}$ & 3 & $2.23 \mathrm{E}-05$ & $2.02 \mathrm{E}-05$ \\
\hline $\begin{array}{l}\text { Ambient temperature in } \\
\text { scenario }\left({ }^{\circ} \mathrm{C}\right)\end{array}$ & 3 & 21 & 5.44 \\
\hline Side slope & 3 & 0.4 & 0.2 \\
\hline Flow velocity $(\mathrm{m} / \mathrm{d})$ & 3 & 0.8 & 0.061 \\
\hline
\end{tabular}

and van der Zande, 2003). A simple first-tier assessment was used for estimating spray drift when using conventional application equipment.

\section{Results and discussion}

\section{Pesticides used: Amounts and chemical characteristics}

Environmentally relevant physico-chemical properties and characteristics of the 17 pesticides used on various crops are presented in Table 1. These values were used to populate the models. Toxicity values for various trophic levels for each of the pesticides used in the PRIMET model are given in Table 2. The parameter values of the water body used to calculate the first-tier ETR values by PRIMET (for the physical scenario parameters) are presented in Table 3.

\section{Application of the PRIMET model}

For the aquatic risk assessment, the ETR was calculated using the average application rate and toxicity values available for the 17 pesticides (Tables 2 and 4) applied to the worst-case scenario. Either a 'no risk' or 'possible risk' category was indicated for most pesticides studied, with a 'definite risk' not being indicated for any of the pesticides within the aquatic environment.

\section{Pesticides indicating 'No risk'}

The PRIMET model calculated low ETR values $(<1)$ for cyromazine $(\mathrm{ETR}=0.00014 ; \mathrm{PEC}=0.12 \mu \mathrm{g} / \ell)$; bentazone $(\mathrm{ETR}=$ $0.00049 ; \mathrm{PEC}=1.1 \mu \mathrm{g} / \ell) ;$ alachlor $(\mathrm{ETR}=0.061 ; \mathrm{PEC}=3.5 \mu \mathrm{g} / \ell)$; endosulfan $(\mathrm{ETR}=0.067$; $\mathrm{PEC}=0.0026 \mu \mathrm{g} / \ell)$; $\operatorname{captan}(\mathrm{ETR}=$ $0.2 ; \mathrm{PEC}=0.25 \mu \mathrm{g} / \ell)$; pendimethalin $(\mathrm{ETR}=0.3 ; \mathrm{PEC}=0.84$ $\mu \mathrm{g} / \ell)$; abamectin $(\mathrm{ETR}=0.45 ; \mathrm{PEC}=0.0068 \mu \mathrm{g} / \ell)$ and fenamiphos $(\mathrm{ETR}=0.46 ; \mathrm{PEC}=3.1 \mu \mathrm{g} / \ell)$ indicating no predicted risks of these compounds to the aquatic ecosystem (Table 4).

Cyromazine was found to have been frequently used in relatively small quantities (136.64 g a.i./ha). It was applied at an interval of $7 \mathrm{~d}$ on average 6 times in a season in the study area, where it was mainly used on spinach. Numerous laboratory and field studies conducted demonstrate that cyromazine was efficiently degraded by biological mechanisms and had a low toxicity to aquatic organisms (Tomlin, 2000). Normal application of 
TABLE 4

Pesticides used in the mixed agriculture study area and relevant application rates assessed from field surveys as well as the recommended dosage applied

\begin{tabular}{|c|c|c|c|c|c|c|c|c|}
\hline $\begin{array}{l}\text { Active ingredi- } \\
\text { ent }\end{array}$ & $\begin{array}{l}\text { a Applied/ } \\
\text { Recom- } \\
\text { mended } \\
\text { dose } \\
\text { (g a.i./ha) }\end{array}$ & $\begin{array}{l}\text { Applica- } \\
\text { tion } \\
\text { interval } \\
\text { (days) }\end{array}$ & $\begin{array}{l}\text { Number of } \\
\text { applica- } \\
\text { tions }\end{array}$ & $\begin{array}{c}\text { d Spray drift } \\
\text { (\%) }\end{array}$ & $\begin{array}{l}\text { PEC } 1 \\
\text { water } \\
(\mu \mathrm{g} / \ell)\end{array}$ & $\begin{array}{l}\text { PEC n } \\
\text { water } \\
\text { ( } \mu \mathrm{g} / \mathrm{l})\end{array}$ & PNEC water & \begin{tabular}{|c|} 
ETR \\
(PEC/PNEC)
\end{tabular} \\
\hline Deltamethrin & 29 & 3 & 5 & 1 & 0.021 & 0.037 & 0.0005 & 75 \\
\hline Cypermethrin & 112 & 7 & 6 & 1 & 0.08 & 0.2 & 0.0036 & 55 \\
\hline Parathion & 813 & 7 & 2 & 1 & 0.58 & 0.58 & 0.03 & 20 \\
\hline Dichlorvos & 861 & 21 & 2 & 1 & 0.63 & 0.63 & 0.033 & 19 \\
\hline Carbaryl & 2513 & 7 & 3 & 1 & 1.8 & 3.7 & 0.54 & 6.8 \\
\hline Bromoxynil & 420 & 3 & 2 & 1 & 0.31 & 0.31 & 0.11 & 2.8 \\
\hline Methomyl & 2943 & 5 & 8 & 1 & 2.1 & 5.1 & 3.7 & 1.4 \\
\hline Linuron & 1495 & 7 & 2 & 1 & 1.1 & 1.1 & 0.7 & 1.6 \\
\hline Aldicarb & 17803 & 365 & 1 & 1 & 13 & 13 & 9.5 & 1.4 \\
\hline Fenamiphos & 4221 & 30 & 3 & 1 & 3.1 & 3.1 & 6.6 & 0.46 \\
\hline Abamectin & 6.1 & 14 & 2 & 1 & 0.0044 & 0.0068 & 0.015 & 0.45 \\
\hline Pendimethalin & 1359 & 45 & 2 & 1 & 0.84 & 0.84 & 2.8 & 0.3 \\
\hline Captan & 348 & 10 & 6 & 1 & 0.25 & 0.25 & 1.3 & 0.2 \\
\hline Endosulfan & 864 & 10 & 3 & 1 & 0.0012 & 0.0026 & 0.039 & 0.067 \\
\hline Alachlor & 3402 & 45 & 2 & 1 & 2.5 & 3.5 & 57 & 0.061 \\
\hline Betazone & 1508 & 7 & 2 & 1 & 1.1 & 1.1 & 2300 & 0.00049 \\
\hline Cyromazine & 137 & 7 & 6 & 1 & 0.099 & 0.12 & 900 & 0.00014 \\
\hline \multicolumn{9}{|c|}{$\begin{array}{l}\text { a Average pesticide application dose according to spraying programme. } \\
{ }^{b} \text { Application interval } \\
{ }^{c} \text { Number of applications } \\
{ }^{d} \text { Spray drift calculated using IMAG drift calculator }\end{array}$} \\
\hline
\end{tabular}

bentazone was considered unlikely to be hazardous to most nontarget organisms because of its negligibly low toxicity (based on available data) and low application rates (US EPA, 1985; Huber and Otto, 1994). The high PNEC values for cyromazine $(900 \mu \mathrm{g} / \ell)$ and bentazone $(2300 \mu \mathrm{g} / \ell)$ were a consequence of their overall lower toxicity to aquatic organisms. They were therefore regarded as posing a low risk to the aquatic ecosystem.

Alachlor and pendimethalin are pre-emergence herbicides and were found to have been extensively used within the study area. Alachlor has a moderate persistence and is moderately toxic to fish and aquatic invertebrates and is highly toxic to primary producers (Johnson and Finley, 1980; US EPA, 1997). It was found to be mainly used on maize crops within the study area. Pendimethalin was mainly applied to tobacco in the study area. Pendimethalin does not represent a high risk to aquatic animals and plants. According to the US EPA R.E.D. fact sheet (1997) pendimethalin has a high affinity to bind to soil and sediment particles and should limit concentrations in surface water. Endosulfan is an organochlorine insecticide applied to a number of crops in the study area including tobacco, vegetables, citrus, grapes and maize. Endosulfan is highly toxic to both fish and aquatic invertebrates (Tomlin, 2000). Although it readily degrades in water, it binds strongly to sediments and can be slowly released back into the water column. This produces low concentrations for many months (Peterson and Batley, 1991). Bollmohr et al. (2007) reported an endosulfan environmental concentration of $0.16 \mu \mathrm{g} / \ell$ in water. This value was above the PEC value predicted in this study. This is probably attributed to differing scenarios, but is most likely due to the lower application rate found in this study area. Abamectin was applied in relatively small dosages $(6.14 \mathrm{~g}$ a.i./ha) and was mainly applied to vegetables (lettuce, spinach and peppers), onions, grapes, maize, and potatoes in the study area. According to the US EPA (1990) abamectin is highly toxic to aquatic invertebrates. Concentrations in the water, however, are expected to be low mainly due to photodegradation and adsorption of this pesticide by sediments. It is also rapidly degraded by soil micro-organisms and becomes less toxic to aquatic organisms (Wislocki et al., 1989). This pesticide does not bioaccumulate (Tomlin, 2000). Fenamiphos is mainly applied to grapes, citrus, tobacco, soya beans, beans and vegetables (cabbage, lettuce and peppers). It readily degrades in water and is also degradable on soil surfaces. Based on $\mathrm{K}_{\mathrm{oc}}$ values and leaching studies, fenamiphos can be classified as a compound with low mobility (Tomlin, 2000). Fenamiphos is regarded as having a high toxicity to aquatic organisms but will not substantially bioaccumulate (Smith, 1993). Last of the pesticides indicated to pose no risk is the fungicide, captan, which is mainly applied to sunflowers, grapes, and onions in the study area. Captan is known to be slightly toxic to aquatic invertebrates and has a moderate tendency to bioaccumulate in living tissue of aquatic organisms (Tomlin, 2000). Captan is nonvolatile and rapidly hydrolyzes in water and in this way the risk of this chemical to aquatic life is reduced (Wolfe et al., 1976).

\section{Pesticides indicating a 'possible risk'}

Analysis of the application patterns of aldicarb (ETR $=1.4$; PEC $=13 \mu \mathrm{g} / \ell) ;$ methomyl $(\mathrm{ETR}=1.4 ; \mathrm{PEC}=5.1 \mu \mathrm{g} / \ell) ;$ linuron $(\mathrm{ETR}$ $=1.6 ; \mathrm{PEC}=1.1 \mu \mathrm{g} / \ell) ;$ bromoxynil $(\mathrm{ETR}=2.8 ; \mathrm{PEC}=0.31 \mu \mathrm{g} / \ell)$; carbaryl $(\mathrm{ETR}=6.8 ; \mathrm{PEC}=3.7 \mu \mathrm{g} / \ell)$ dichlorvos $(\mathrm{ETR}=19 ; \mathrm{PEC}$ $=0.63 \mu \mathrm{g} / \ell)$; parathion $(\mathrm{ETR}=20 ; \mathrm{PEC}=0.58 \mu \mathrm{g} / \ell)$ and two pyrethroids, cypermethrin $(\mathrm{ETR}=55 ; \mathrm{PEC}=0.2 \mu \mathrm{g} / \ell)$ and deltamethrin $(\mathrm{ETR}=75 ; \mathrm{PEC}=0.037 \mu \mathrm{g} / \ell)$ indicated the possibility of a risk occurring at their respective predicted environmental concentrations calculated by the PRIMET model (Table 4). 


\begin{tabular}{|c|c|c|c|c|c|c|c|}
\hline \multicolumn{8}{|c|}{$\begin{array}{c}\text { TABLE } 5 \\
\text { The percentage probability of effect classes (No Effect, Slight Effect and Clear Effect) for eight grouped } \\
\text { ecological endpoints with the respective lower (5\%) and upper confidence interval (95\%) in parenthesis } \\
\text { for each of the selected insecticides }\end{array}$} \\
\hline Insecticide & $\begin{array}{l}\text { Aldicarb } \\
(13 \mu \mathrm{g} / \ell)\end{array}$ & $\begin{array}{l}\text { Carbaryl } \\
(3.7 \mu \mathrm{g} / \mathrm{\ell})\end{array}$ & $\begin{array}{c}\text { Cyper- } \\
\text { methrin } \\
(0.2 \mu \mathrm{g} / \mathrm{l})\end{array}$ & $\begin{array}{c}\text { Delta- } \\
\text { methrin } \\
(0.037 \mu \mathrm{g} / \ell)\end{array}$ & $\begin{array}{l}\text { Dichlorvos } \\
(0.63 \mu \mathrm{g} / \ell)\end{array}$ & $\begin{array}{c}\text { Methomyl } \\
(5.1 \mu \mathrm{g} / \ell)\end{array}$ & $\begin{array}{l}\text { Parathion } \\
(0.58 \mu \mathrm{g} / \ell)\end{array}$ \\
\hline $\begin{array}{l}\text { Community metabolism } \\
\text { Probability of no effect } \\
\text { Probability of slight effect } \\
\text { Probability of clear effect }\end{array}$ & $\begin{array}{l}\mathrm{n}=3 \\
100(100) \\
0(0) \\
0(0)\end{array}$ & $\begin{aligned} \mathrm{n} & =11 \\
100 & (100 \\
0 & (0) \\
0 & (0)\end{aligned}$ & $\begin{array}{l}\mathrm{n}=28 \\
93(83-100) \\
4(0-12) \\
3(0-11)\end{array}$ & $\begin{array}{l}\mathrm{n}=30 \\
94(85-100) \\
3(0-10) \\
3(0-9)\end{array}$ & $\begin{array}{c}\mathrm{n}=13 \\
100(100) \\
0(0) \\
0(0))\end{array}$ & $\begin{array}{l}\mathrm{n}=3 \\
00(100) \\
0(0) \\
0(0)\end{array}$ & $\begin{array}{l}\mathrm{n}=13 \\
00(100) \\
0(0) \\
0(0)\end{array}$ \\
\hline $\begin{array}{l}\text { Algae \& macrophytes } \\
\text { Probability of no effect } \\
\text { Probability of slight effect } \\
\text { Probability of clear effect }\end{array}$ & $\begin{array}{r}\mathrm{n} \\
100 \\
0 \\
0 \\
\end{array}$ & $\begin{array}{c}\mathrm{n}=14 \\
90(64-100) \\
0(0) \\
9(0-37) \\
\end{array}$ & $\begin{array}{c}\mathrm{n}=30 \\
90(77-100) \\
7(0-20) \\
3(0-10) \\
\end{array}$ & $\begin{array}{c}\mathrm{n}=31 \\
94(85-100) \\
3(0-10) \\
3(0-9) \\
\end{array}$ & $\begin{array}{c}\mathrm{n}=17 \\
95(86-100) \\
0(0) \\
5(0-15) \\
\end{array}$ & $\begin{array}{c}\mathrm{n}=5 \\
100(100) \\
0(0) \\
0(0)\end{array}$ & $\begin{array}{c}\mathrm{n}=17 \\
94(87-100) \\
0(0) \\
6(0-14)\end{array}$ \\
\hline $\begin{array}{l}\text { Fish } \\
\text { Probability of no effect } \\
\text { Probability of slight effect } \\
\text { Probability of clear effect }\end{array}$ & $\begin{array}{c}\mathrm{n}=1 \\
100(100 \\
0(0) \\
0(0)\end{array}$ & $\begin{array}{c}\mathrm{n}=9 \\
100(100) \\
0(0) \\
0(0)\end{array}$ & $\begin{array}{c}\mathrm{n}=20 \\
80(60-100) \\
20(0-40) \\
0(0)\end{array}$ & $\begin{array}{c}\mathrm{n}=19 \\
80(63-100) \\
20(0-38) \\
0(0)\end{array}$ & $\begin{array}{c}\mathrm{n}=12 \\
100(100) \\
0(0) \\
0(0)\end{array}$ & $\begin{array}{c}\mathrm{n}=1 \\
100(100) \\
0(0) \\
0(0)\end{array}$ & $\begin{array}{c}\mathrm{n}=12 \\
100(100) \\
0(0) \\
0(0)\end{array}$ \\
\hline $\begin{array}{l}\text { Insects } \\
\text { Probability of no effect } \\
\text { Probability of slight effect } \\
\text { Probability of clear effect }\end{array}$ & $\begin{array}{c}\mathrm{n}=1 \\
100(100) \\
0(0) \\
0(0)\end{array}$ & $\begin{array}{c}\mathrm{n}=13 \\
67(35-100) \\
0(0) \\
33(0-65)\end{array}$ & $\begin{array}{c}\mathrm{n}=31 \\
0(0) \\
4(0-11) \\
96(89-100)\end{array}$ & $\begin{array}{c}\mathrm{n}=32 \\
0(0) \\
0(0) \\
100(100)\end{array}$ & $\begin{array}{c}\mathrm{n}=15 \\
78(52-97) \\
3(0-10) \\
19(1-44)\end{array}$ & $\begin{array}{c}\mathrm{n}=2 \\
100(100) \\
0(0) \\
0(0)\end{array}$ & $\begin{array}{c}\mathrm{n}=15 \\
69(32-97) \\
4(0-14) \\
27(1-63)\end{array}$ \\
\hline $\begin{array}{l}\text { Macro-crustaceans } \\
\text { Probability of no effect } \\
\text { Probability of slight effect } \\
\text { Probability of clear effect }\end{array}$ & $\begin{array}{c}\mathrm{n}=1 \\
100(100) \\
0(0) \\
0(0)\end{array}$ & $\begin{array}{c}\mathrm{n}=7 \\
72(34-100) \\
14(0-48) \\
14(0-48)\end{array}$ & $\begin{array}{c}\mathrm{n}=24 \\
0(0) \\
0(0) \\
100(100)\end{array}$ & $\begin{array}{c}\mathrm{n}=26 \\
0(0) \\
0(0) \\
100(100)\end{array}$ & $\begin{array}{c}\mathrm{n}=9 \\
63(19-100) \\
19(0-61) \\
18(0-50)\end{array}$ & $\begin{array}{c}\mathrm{n}=1 \\
100(100) \\
0(0) \\
0(0)\end{array}$ & $\begin{array}{c}\mathrm{n}=9 \\
66(28-100) \\
14(0-45) \\
20(0-57)\end{array}$ \\
\hline $\begin{array}{l}\text { Micro-crustaceans } \\
\text { Probability of no effect } \\
\text { Probability of slight effect } \\
\text { Probability of clear effect }\end{array}$ & $\begin{array}{c}\mathrm{n}=6 \\
16(3-100) \\
84(0-96) \\
0(0)\end{array}$ & $\begin{array}{c}\mathrm{n}=20 \\
22(8-44) \\
50(5-77) \\
29(5-62)\end{array}$ & $\begin{array}{c}\mathrm{n}=35 \\
43(24-60) \\
6(0-13) \\
51(34-70)\end{array}$ & $\begin{array}{c}\mathrm{n}=37 \\
41(24-57) \\
4(0-10) \\
55(38-72)\end{array}$ & $\begin{array}{c}\mathrm{n}=24 \\
58(34-80) \\
13(3-29) \\
29(7-53)\end{array}$ & $\begin{array}{c}\mathrm{n}=7 \\
14(2-64) \\
86(36-100) \\
0(0)\end{array}$ & $\begin{array}{c}\mathrm{n}=24 \\
33(15-79) \\
22(3-55) \\
45(5-72)\end{array}$ \\
\hline $\begin{array}{l}\text { Other micro-invertebrates } \\
\text { Probability of no effect } \\
\text { Probability of slight effect } \\
\text { Probability of clear effect }\end{array}$ & $\begin{array}{c}\mathrm{n}=1 \\
100(100) \\
0(0) \\
0(0)\end{array}$ & $\begin{array}{c}\mathrm{n}=8 \\
100(100) \\
0(0) \\
0(0)\end{array}$ & $\begin{array}{c}\mathrm{n}=23 \\
95(86-100) \\
0(0) \\
4(0-14)\end{array}$ & $\begin{array}{c}\mathrm{n}=23 \\
96(88-100) \\
0(0) \\
4(0-13)\end{array}$ & $\begin{array}{c}\mathrm{n}=9 \\
97(86-100) \\
0(0) \\
3(0-14)\end{array}$ & $\begin{array}{c}\mathrm{n}=1 \\
100(100) \\
0(0) \\
0(0)\end{array}$ & $\begin{array}{c}\mathrm{n}=9 \\
94(77-100) \\
0(0) \\
6(0-24)\end{array}$ \\
\hline $\begin{array}{l}\text { Rotifers } \\
\text { Probability of no effect } \\
\text { Probability of slight effect } \\
\text { Probability of clear effect }\end{array}$ & $\begin{array}{c}\mathrm{n}=2 \\
100(100) \\
0(0) \\
0(0)\end{array}$ & $\begin{array}{c}\mathrm{n}=9 \\
89(63-100) \\
0(0) \\
11(0-39)\end{array}$ & $\begin{array}{c}\mathrm{n}=30 \\
73(57-89) \\
0(0) \\
27(11-43)\end{array}$ & $\begin{array}{c}\mathrm{n}=32 \\
77(60-91) \\
0(0) \\
23(10-41)\end{array}$ & $\begin{array}{c}\mathrm{n}=10 \\
91(67-100) \\
0(0) \\
9(0-33)\end{array}$ & $\begin{array}{c}\mathrm{n}=2 \\
100(100) \\
0(0) \\
0(0)\end{array}$ & $\begin{array}{c}\mathrm{n}=10 \\
90(67-100) \\
0(0) \\
10(0-33)\end{array}$ \\
\hline
\end{tabular}

Aldicarb is a carbamate insecticide, nematicide and acaricide that is applied to tobacco, grapes, beans, potatoes, citrus fruit, cotton and sorghum at very high single dose applications (17 $803 \mathrm{~g}$ a.i./ha) in the study area, resulting in a high predictive environmental concentration. PRIMET takes into consideration multiple or single applications and does not determine the cumulative pesticide inputs from various farmers spraying simultaneously. Volatilisation from water and bioaccumulation in animal tissue do not seem to be an important fate process due to its high solubility in water. Aldicarb is a highly toxic pesticide (PAN, 2006) that may have a significant chronic effect on aquatic biota (Foran et al., 1985). Aldicarb will pose a potential risk to the aquatic system due to its persistent nature in water and soils. The PEC value of $13 \mu \mathrm{g} / \ell$ given in this study area is higher than the Canadian Water Quality Guideline values (reported as $1 \mu \mathrm{g} / \ell$ for the protection of aquatic life) and will pose a potential risk to the aquatic ecosystem. Linuron is a herbicide applied mainly to carrots, celery, soya beans and potatoes at a rate of $1000 \mathrm{~g}$ a.i./ha. Microbial degradation is the primary factor in disappearance of this substance from soil. Linuron was recorded to be highly toxic to aquatic plants (US EPA, 1984) and according to Cuppen et al. (1997), under normal application in agricultural fields, will not greatly affect species composition of invertebrates in adjacent aquatic ecosystems. Methomyl is an insecticide and acaricide applied to vegetables (cabbage, lettuce and spinach), tobacco, grapes, onions, potatoes, citrus, wheat and sorghum. It is indicated to have a moderate to high toxicity for fish, being even more toxic to invertebrates. Bromoxynil is a herbicide used for pests associated with maize, wheat, sorghum and onions. It is known to be highly toxic to zooplankton and moderately toxic to molluscs. Carbaryl is a carbamate insecticide that is used on a variety of crops to mainly control sucking insects and is also toxic to beneficial insects (Tomlin, 2000). It is highly toxic to invertebrates; but has a lower toxicity to fish. Carbaryl is known to accumulate in aquatic organisms (EXTOXNET, 2004). This risk is lowered under alkaline conditions (such as those found within the study area) (Baron, 1991). It is applied to a variety of crops in the study area including citrus crops, tobacco, grapes and some vegetables. Under this specific scenario and application regime, a PEC value of 3.7 $\mu \mathrm{g} / \ell$ was predicted to occur in the study area. Dichlovos is an insecticide and acaricide used in the study area on spinach, cabbage, other vegetable crops and on grapes. The Environmental Health Criteria (EHC) review concluded that, with the excep- 


\begin{tabular}{|c|c|c|}
\hline \multicolumn{3}{|c|}{$\begin{array}{c}\text { TABLE } 6 \\
\text { The percentage probability of effect classes } \\
\text { (no effect, slight effect and clear effect ) for } 8 \\
\text { grouped ecological endpoints with the respective } \\
\text { lower confidence interval (5\%) and upper confi- } \\
\text { dence interval ( } 95 \%) \text { in parenthesis for two of the } \\
\text { selected herbicides. }\end{array}$} \\
\hline Herbicides & $\begin{array}{c}\text { Linuron } \\
(1.1 \mu \mathrm{g} / \mathrm{\ell})\end{array}$ & $\begin{array}{c}\text { Bromoxynil } \\
(0.31 \mu \mathrm{g} / \mathrm{\ell})\end{array}$ \\
\hline $\begin{array}{l}\text { Community metabolism } \\
\text { Probability of no effect } \\
\text { Probability of slight effect } \\
\text { Probability of clear effect }\end{array}$ & $\begin{array}{c}\mathrm{n}=28 \\
60(20-80) \\
21(4-51) \\
20(5-51)\end{array}$ & $\begin{array}{c}\mathrm{n}=19 \\
80(61-100) \\
15(0-32) \\
5(0-15)\end{array}$ \\
\hline $\begin{array}{l}\text { Macrophytes } \\
\text { Probability of no effect } \\
\text { Probability of slight effect } \\
\text { Probability of clear effect }\end{array}$ & $\begin{array}{c}\mathrm{n}=19 \\
75(25-96) \\
3(0-13) \\
22(3-62)\end{array}$ & $\begin{array}{c}\mathrm{n}=7 \\
100(100) \\
0(0) \\
0(0)\end{array}$ \\
\hline $\begin{array}{l}\text { Fish \& Tadpoles } \\
\text { Probability of no effect } \\
\text { Probability of slight effect } \\
\text { Probability of clear effect }\end{array}$ & $\begin{array}{c}\mathrm{n}=6 \\
85(49-100) \\
0(0) \\
15(0-51) \\
\end{array}$ & $\begin{array}{l}\mathrm{n}=0 \\
0(0) \\
0(0) \\
0(0)\end{array}$ \\
\hline $\begin{array}{l}\text { Macro-crustaceans \& Insects } \\
\text { Probability of no effect } \\
\text { Probability of slight effect } \\
\text { Probability of clear effect }\end{array}$ & $\begin{array}{c}\mathrm{n}=6 \\
94(33-100) \\
3(0-33) \\
3(0-40) \\
\end{array}$ & $\begin{array}{c}\mathrm{n}=3 \\
67(0-100) \\
33(0-100) \\
0(0)\end{array}$ \\
\hline $\begin{array}{l}\text { Molluscs } \\
\text { Probability of no effect } \\
\text { Probability of slight effect } \\
\text { Probability of clear effect }\end{array}$ & $\begin{array}{c}\mathrm{n}=7 \\
100(100) \\
0(0) \\
0(0)\end{array}$ & $\begin{array}{c}\mathrm{n}=2 \\
100(100) \\
0(0) \\
0(0)\end{array}$ \\
\hline $\begin{array}{l}\text { Periphyton } \\
\text { Probability of no effect } \\
\text { Probability of slight effect } \\
\text { Probability of clear effect }\end{array}$ & $\begin{array}{c}\mathrm{n}=26 \\
87(65-96) \\
4(0-9) \\
9(2-28)\end{array}$ & $\begin{array}{c}\mathrm{n}=10 \\
91(69-100) \\
0(0) \\
9(0-31)\end{array}$ \\
\hline $\begin{array}{l}\text { Phytoplankton } \\
\text { Probability of no effect } \\
\text { Probability of slight effect } \\
\text { Probability of clear effect }\end{array}$ & $\begin{array}{c}\mathrm{n}=23 \\
77(40-96) \\
3(0-7) \\
20(2-60) \\
\end{array}$ & $\begin{array}{c}\mathrm{n}=9 \\
87(61-100) \\
13(0-40) \\
0(0) \\
\end{array}$ \\
\hline $\begin{array}{l}\text { Zooplankton } \\
\text { Probability of no effect } \\
\text { Probability of slight effect } \\
\text { Probability of clear effect }\end{array}$ & $\begin{array}{c}\mathrm{n}=24 \\
100(100) \\
0(0) \\
0(0)\end{array}$ & $\begin{array}{c}\mathrm{n}=9 \\
100(100) \\
0(0) \\
0(0)\end{array}$ \\
\hline
\end{tabular}

tion of gross spillage, recommended use does not constitute a hazard for aquatic and terrestrial organisms (Tomlin, 2000). It is non-persistent in the environment with rapid decomposition in the atmosphere (Tomlin, 2000). Parathion is classified as a compound with low mobility based on $\mathrm{K}_{\mathrm{oc}}$ values and leaching studies. Parathion is rapidly degraded under laboratory and field conditions (Tomlin, 2000). It is an organophosphate insecticide and acaricide which has a moderate toxicity to aquatic invertebrates and fish (Mulla and Mian, 1981). Parathion was applied to vegetables (cabbage, cucumber and lettuce), grapes, tobacco, maize, and cotton within the study area. Cypermethrin is a pyrethroid insecticide used on cabbage, lettuce and onions as well as tobacco and maize in the study area. The EHC concluded that biological degradation is rapid, with the subsequential levels of cypermethrin and its degradation products in soil and surface waters being very low (Tomlin, 2000). Thus, under field conditions, fish are not expected to be at risk from normal agricultural usage of cypermethrin even though it is classified as being highly toxic to invertebrates and vertebrates. Bollmohr et al. (2007) indicated an acute exposure toxicity ratio of 0.01 based on calculated concentrations found in water of 0.001 $\mu \mathrm{g} / \ell$. The PEC value given by PRIMET was higher than these estimates $(0.2 \mu \mathrm{g} / \ell)$ thus resulting in a higher ETR of 55 . This value translates into higher potential risk. Deltamethrin is also a pyrethroid insecticide that is highly toxic to fish under laboratory conditions using a continuous exposure but is not toxic to fish under natural conditions using a natural exposure regime. Deltamethrin undergoes microbial degradation within 1 to 2 weeks of application (Tomlin, 2000) and was mostly used on cotton, maize, spinach, grapes, and soya beans as well as for animal husbandry. Only low dosages were, however, used (29 $\mathrm{g}$ a.i./ha) in the study area on these crops. Toxicity to aquatic arthropods is indicated to present an environmental hazard if applications are intensive (Solomon et al., 2001). The relatively low PNEC for these 2 pyrethroid pesticides is a consequence of their high toxicity to aquatic arthropods and fish. Pyrethroids (such as cypermethrin and deltamethrin) are highly hydrophobic and have large octanol-water coefficients $\left(\mathrm{K}_{\mathrm{ow}}\right)$. They would bioconcentrate within non-target organisms in the water matrix, resulting in toxicity to both aquatic invertebrates and fish (Van der Werf, 1996; Maund et al., 1997; Solomon et al., 2001). The PRIMET model therefore indicated that the highest possible risk to aquatic organisms will be eminent for these two substances with ETR values of 55 and 75 at 0.2 and $0.037 \mu \mathrm{g} / \ell$ environmental concentrations for cypermethrin and deltamethrin, respectively. Pyrethroids are considered to pose a lesser risk under field conditions as they display high adsorption properties (Schroer et al., 2004).

The pesticides in this mixed agricultural area belong to a variety of groups (namely insecticides (11 of 17), herbicides (5 of 17) and fungicides ( 1 of 17). According to the environmental preliminary risk assessment, 9 of these agrochemicals are indicated to have some degree of impact or effect on non-target aquatic organisms present in the water bodies bordering the fields. The largest risk to this system was calculated for the scenario where deltamethrin was used (Table 4).

\section{PERPEST results}

The PERPEST model was applied to the pesticide crop combination for which only a potential or definite risk was indicated in the first-tier calculation. This analysis yielded the probability of observing a clear effect for the 8 effect classes for the response variables for 7 insecticides (Table 5) and 2 herbicides (Table 6). Deltamethrin (PEC of $0.037 \mu \mathrm{g} / \ell$ ) showed the highest ETR value and therefore a clear effect on insects and macro-crustaceans with a $100 \%$ probability of occurrence shown. The probability of clear effects was indicated as $55 \%$ and $23 \%$ for the microcrustacean and rotifer group endpoints, respectively. Probability of clear effects observed for cypermethrin at the relevant PEC value for macro-crustaceans was $100 \%, 96 \%$ for insects, $51 \%$ for micro-crustaceans and $27 \%$ for rotifers. Other notable pesticide effects on aquatic insects were indicated for carbaryl, parathion and dichlorvos, with $33 \%, 27 \%$ and $19 \%$ probability of clear effects, respectively. The effects of these insecticides on micro-crustaceans were $29 \%, 45 \%$ and $29 \%$ probability of clear effects, respectively. Aldicarb and methomyl did not indicate a clear effect towards all aquatic communities due to no high clear effects shown. Bromoxynil did not indicate clear effects on macrophytes, fish and tadpoles, macro-crustaceans and insects, molluscs, phytoplankton and zooplankton effect classes. Linuron resulted in values of $20 \%, 20 \%$ and $22 \%$ of clear effects for community metabolism, phytoplankton and macrophytes affect classes, respectively. A low clear effect (9\%) was observed 
for bromoxynil in periphyton communities at $0.31 \mu \mathrm{g} / \ell$. Community metabolism, algae, fish and other micro-invertebrates were impacted to a lesser extent by any of the tested insecticides.

The first-tier risk-assessment approach used in this study is based on a worst case scenario using data from short-term standard laboratory tests. These tests aim at maximum and continuous exposure of the organisms (De Jong et al., 2005), whereas in higher-tier methods like the PERPEST effect model, toxicity data are based on more realistic exposure and involves a higher degree of biological complexity. This may incorporate a degree of resilience in the ecosystem that is not determined in singlespecies toxicity tests (De Jong et al., 2005). It is therefore essential to generate additional data on potential effects and exposure to further refine the risks posed to this particular system. By following the TRIAD approach (Chapman, 2000), conducting laboratory (bioassays and meso- or microcosm experiments) and field assessments such as chemical monitoring as well as implementing biomonitoring techniques, a more refined risk assessment can be executed. This will form an important component in validating the findings of this preliminary risk assessment. By implementing these techniques it can be determined how local aquatic species, populations or communities inhabiting these ecosystems are affected.

Data on each of the pesticides' intrinsic properties were taken from literature sources available mostly for the temperate regions of Europe and North America. This has led to uncertainties in application to warmer regions (Kwok et al., 2007). It was, however, indicated by studies conducted by Brock et al. (2000a; 2000b) and Maltby et al. (2005), that no differences in toxicity and sensitivity of tropical and temperate species for selected pesticides (chlorpyrifos, fenitrothion and carbofuran) could be found. It is, however, imperative that higher-tier studies be conducted on pesticides showing potential risks under local conditions. This would not only contribute to the case-base PERPEST database, but will determine how these models differ if more relevant, local data replaced literature-based data from temperate regions. Meinhardt (2008) for example, found that pesticide half-lives determined for South African soil differed from non-localised published data.

It has become evident that the application value of the PERPEST model in South Africa could be enhanced through using actual measured pesticide concentrations in place of PEC values derived from other models. For example, using the results obtained from the extensive work carried out on the Lourens River in the Cape Province (Bollmohr et al., 2007; Schulz, 2001), the predicted effects emanating from the PERPEST model can be compared to actual observed effect data. This would provide ideal validation for the implementation of this model within higher-tier risk assessments.

\section{Conclusions}

The PRIMET model provides an objective method of quantifying and comparing risks of pesticides applied to an agricultural area. The model was effectively used in this study to predict the risks in the aquatic scenario and was found to be user friendly due to easily accessible and available data. The models can also be easily validated and provide an efficient way of combining input variables such as pesticide characteristics, applications and specific scenarios). The results of the tiered risk-assessment approach indicated that several pesticides (carbaryl, cypermethrin, deltamethrin, dichlorvos, parathion and linuron) have the potential to impact non-target species within the aquatic ecosystem. Results from both the PERPEST and PRIMET models indicated that the predicted effects of deltamethrin and cypermethrin pose the greatest risk to aquatic insects and macro-crustaceans within the study area. The approach used in this study offers a significant improvement over the presently-used simulation models or use of safety factors. It is also especially useful in developing countries such as South Africa where such models have not yet been applied. These models are able to assist farmers in reducing their environmental risks in terms of pesticide usage in a user- friendly and cost-effective manner. This is done by giving them an indication of which pesticides at what dosages and applications pose the lowest risk potential in their particular scenarios thereby making for a more responsible environmental choice of pesticide usage. Both models have ample scope for modelling ecological risk assessment in South Africa.

\section{Acknowledgments}

South African Netherlands Research Programme on Alternatives in Development (SANPAD), which is a collaborative research programme financed by the Netherlands Ministry of Foreign Affairs, has generously funded this research with the aim of improving pesticide use and establishing their effects on the environment and on the communities associated with agriculture. Additional financial support was obtained from the National Research Foundation (NRF) and the International Foundation of Science (IFS).

\section{References}

BARON RL (1991) Carbamate insecticides. In: Hayes WJ Jr. and Laws ER Jr (eds.) Handbook of Pesticide Toxicology. Vol. 3. Classes of Pesticides. Academic Press Inc, NY.

BELTMAN WHJ and ADRIAANSE PI (1999) User's Manual TOXSWA 1.2. Simulation of Pesticide Fate in Small Surface Waters. DLO Winand Staring Centre, Technical Document 54. Wageningen, the Netherlands.

BOLLMOHR S, DAY JA and SCHULZ R (2007) Temporal variability in particle-associated pesticide exposure in a temporarily open estuary, Western Cape, South Africa. Chemosphere 68 479-488.

BROCK TCM, LAHR J and VAN DEN BRINK PJ (2000a) Ecological Risk Assessment of Pesticides in Freshwater Ecosystems Part 1: Herbicides. Alterra-Report 088. Wageningen, the Netherlands.

BROCK TCM, VAN WIJINGAARDEN RPA and VAN GEEST G (2000b) Ecological Risk Assessment of Pesticides in Freshwater Ecosystems Part 2: Insecticides. Alterra-Report 089. Wageningen, the Netherlands.

BROCK TCM, ARTS GHP, MALTBY L and VAN DEN BRINK PJ (2006) Aquatic risks of pesticides, ecological protection goals and common aims in EU legislation. Integr. Environ. Assess. Manage. 2 e20-e46.

CHAPMAN PM (2000) The sediment quality triad: then now and tomorrow. Int. J. Environ. Pollut. 13 351-356.

CUPPEN JGM, VAN DEN BRINK PJ, VAN DER WOUSE H, ZWAARDEMAKER N and BROCK TCM (1997) Sensitivity of macrophytedominated freshwater microcosms to chronic levels of the herbicide linuron. Ecotox. Environ. Saf. 38 25-35.

DE JONG FMW, MENSINK BJWG, SMIT CE and MONTFORTS MHMM (2005) Evaluation of ecotoxicological field studies for authorization of plant protection products in Europe. Hum. Ecol. Risk. Assess. 11 1157-1176.

EU (1997) Council Directive 97/57/EC of September 21, 1997; Establishing annex VI to Directive 91/414/EEC concerning the placing of plant protection products on the market. J. Eur. Commun. L265 87-109.

EXTOXNET (2004) Extension Toxicology Network. A Pesticide Information Project of Cooperative Extension Offices of Cornell University, University of California, Michigan State University and Oregon State University. (URL: http://extoxnet.orst.edu/).

FORAN JA, GERMUSKA PJ and DELFINO JJ (1985) Acute toxicity of aldicarb, aldicarb sulfoxide, and aldicarb sulfone to Daphnia laevis. 
Bull. Environ. Contam. Toxicol. 35 546-550.

HOLTERMAN HJ and VAN DE ZANDE JC (2003) IMAG Drift Calculator Version 1.1 User Manual. Draft Report, 7 February 2003. Wageningen, the Netherlands.

HUBER R and OTTO S (1994) Environmental behavior of bentazon herbicide. Rev. Environ. Contam. Toxicol. 137 111-134.

JOHNSON WW and FINLEY MT (1980) Handbook of Acute Toxicity of Chemicals to Fish and Aquatic Invertebrates. US Department of the Interior, Fish and Wildlife Service, Resource Publication 137. Washington D.C.

KOELMANS AA, VAN DER HEIJDE A, KNIJFF, L and AALDERINK RH (2001) Modelling feedbacks between eutrophication and organic contaminant fate and effects in aquatic ecosystems. A review. Water Res. 35 3517-3536.

KWOK KWH, LEUNG KMY, LUI GSG, CHU VKH, LAM PKS, MORRITT II D, MALTBY L, BROCK TCM, VAN DEN BRINK PJ, WARNE, MSJ and CRANE M (2007) Comparison of tropical and temperate freshwater animal species' acute sensitivities to chemicals: Implications for deriving safe extrapolation factors. Integr. Environ. Assess. Manage. 3 (1) 49-67.

LINDERS JBHJ and LUTTIK R (1995) Uniform system for the evaluation of substances. V. Espe, Risk Assessment for pesticides. Chemosphere 31 (5) 3237-3248.

LEVITAN L, MERWIN I and KOVACH J (1995) Assessing the relative environmental impacts of agricultural pesticides: the quest for a holistic method. Agric. Ecosyst. Environ. 55 153-168.

LONDON L, DALVIE MA, NOWICKI A and CAIRNCROSS E (2005) Approaches for regulating water in South Africa for the presence of pesticides. Water SA 31 (1) 53-59. http://www.wrc.org.za/downloads/ watersa/2005/Jan-05/1751.pdf

MALTBY L, BLAKE N, BROCK TCM and VAN DEN BRINK PJ (2005) Insecticide species sensitivity distributions: the importance of test species selection and relevance to aquatic ecosystems. Environ. Toxicol. Chem. 24 (2) 379-388.

MAUND SJ, SHERRATT TN, STICKLAND T, BIGGS J, WILLIAMS P, SHILLABEER N and JEPSON PC (1997) Ecological considerations in pesticide risk assessment for aquatic ecosystems. Pestic. Sci. 49 185-190

MEINHARDT HR (2008) Evaluation of Predictive Models for Pesticide Behaviour in South African Soils. Ph.D. Thesis, North-West University, Potchefstroom, South Africa.

MULLA MS and MIAN LS (1981) Biological and environmental impacts of the insecticides malathion and parathion on non-target biota in aquatic ecosystems. Residue Rev. 78 100-135.

PAN (2006) Pesticide Database PAN International Website. Accessed June 2006 at URL: http://www.pesticideinfo.org/IndexContent.html

PETERSON SM and BATLEY GE (1991) Fate and Transport of Endosulfan and Diuron in Aquatic Ecosystems. Investigation Report CET/ LH/IRO 13, CSIRO Division of Coal and Energy Technology, Lucas Heights, NSW, Australia.

POSTHUMA L, SUTER GW and TRAAS TP (2002) Species-Sensitivity Distributions in Ecotoxicology. Lewis Publishers, Boca Raton, FL, USA.

SATAPORNVANIT K, BAIRD DJ, LITTLE DC, MILWAIN GK, VAN DEN BRINK PJ, BELTMAN WHJ, NOGUEIRA AJA, DAAM MA, DOMINGUES I, KODITHUWAKKU SS, PERERA MWP, YAKUPITIYAGE A, SURESHKUMAR SN and TAYLOR GJ (2004) Risks of pesticide use in aquatic ecosystems adjacent to mixed vegetable and monocrop fruit growing areas in Thailand. Australas. J. Ecotoxicol. 10 85-95.

SCHROER AFW, BELGERS JDM, BROCK TCM, MATSER AM, MAUND SJ and VAN DEN BRINK PJ (2004) Comparison of laboratory single species and field population-level effects of the pyrethroid insecticide $\lambda$-cyhalothrin on freshwater invertebrates. Arch. Environ. Contam. Toxicol. 46 324-335.

SCHULZ R (2001) Comparison of spray-drift- and runoff-related input of azinphos-methyl and endosulfan from fruit orchards into the Lourens River, South Africa. Chemosphere 45 543-551.

SMITH GJ (1993) Toxicology and Pesticide Use in Relation to Wildlife: Organophosphorus and Carbamate Compounds. CK Smokey. Baco Raton, FL.
SOLOMON KR, GIDDINGS JM and MAUND SJ (2001) Probabilistic risk assessment of cotton pyrethroids: I. Distribution analyses of laboratory aquatic toxicity data. Environ. Toxicol. Chem. 20 652-659.

TESFAMICHAEL AA and KALUARACHCHI JJ (2006) A methodology to assess the risk of an existing pesticide and potential future pesticides for regulatory decision-making. Environ. Sci. \& Pol. 9 275-290.

TIKTAK A, VAN DEN BERG F, BOESTEN JJTI, LEISTRA M, VAN DER LINDEN AWA and VAN KRAALINGEN D (2000) Pesticide Emission Assessment at Regional and Local Scales: User Manual of FOCUS Pearl Version 1.1.1. RIVM Report 711401008, Alterra Report 28, RIVM, Bilthoven 142pp.

TOMLIN CDS (2000) The Pesticide Manual (12 ${ }^{\text {th }}$ edn.) British Crop Protection Council, Farnham, UK.

TRAAS TP, JANSE JH, ALDENBERG T and BROCK TCM (1998) A food web model for fate, direct and indirect effects of Dursban 4E (a.i. chlorpyrifos) in freshwater microcosms. Aquat. Ecol. 32 179-190.

US EPA (1984) Chemical Fact Sheet Number 28: Linuron. Office of Pesticide and Toxic Substances, Washington D.C, 9-13.

US EPA (1985) Chemical Fact Sheet Number 64: Bentazon and sodium bentazon. Office of Pesticide and Toxic Substances, Washington D.C, $10-73$.

US EPA (1990) Pesticide Fact Sheet Number 89.2: Avermectin B1. Office of Pesticide and Toxic Substances, Washington DC. 10-143.

US EPA (1997) The Acetanilide Pesticides: Alachlor, metachlor and acetochlor. Office of Pesticide Programs, U.S. Government Printing Office, Washington D.C.

US EPA R.E.D. (1997) R.E.D. Facts: Pendimethalin. USEPA, Office of Pesticides and Toxic Substances, Washington D.C.

US EPA AQUIRE (AQUatic toxicity Information REtrieval Database) (2006) U.S. Environmental Protection Agency, Washington D.C., Office of Research and Development National Health and Environmental Effects Research Laboratory, Mid-Continent Ecological Division, Duluth, MN, USA. Accessed June 2006 at URL: http://www. epa.gov/med/databases/aquire.html

VAN DEN BRINK PJ, ROELSMA J, VAN NES EH, SCHEFFER M and BROCK TCM. (2002) PERPEST model, a case-based reasoning approach to Predict Ecological Risks of PESTicides. Environ. Toxicol. Chem. 21 (11) 2500-2506.

VAN DEN BRINK PJ, SURESHKUMAR N, DAAM MA, DOMINGUES I, MILWAIN GK, BELTMAN WHJ, PERERA MWP and SATAPORNVANIT K (2003) Environmental and Human Risks of Pesticide Use in Thailand and Sri Lanka. Results of a Preliminary Risk Assessment. Alterra-Report 789, Wageningen, the Netherlands.

VAN DEN BRINK PJ, TER HORST MMS, BELTMAN WHJ, VLAMING J and VAN DEN BOSCH H (2005) PRIMET Version 1.0, Manual and Technical Description. Alterra Report No. 1185. Wageningen, the Netherlands.

VAN DEN BRINK PJ, BROWN CD and DUBUS IG (2006) Using the expert model PERPEST to translate measured and predicted pesticide exposure data into ecological risks. Ecol. Model. 191 106-117.

VAN DEN BRINK PJ, BAVECO JM, VERBOOM J and HEIMBACH F (2007) An individual-based approach to model spatial population dynamics of invertebrates in aquatic ecosystems after pesticide contamination. Environ. Toxicol. Chem. 26 (10) 2226-2236.

VAN DER MERWE A (2005) Personal communication. Laeveld Agrochem, Brits, South Africa

VAN DER WERF HMG (1996) Assessing the impacts of pesticides on the environment. Agric. Ecosyst. Environ. 60 80-96.

VAN NES EH and VAN DEN BRINK PJ (2003) PERPEST Version 1.0, Manual and Technical Description: A Model that Predicts the Ecological Risks of PESTicides in Freshwater Ecosystems. Alterra Report No. 787. Wageningen, the Netherlands.

WEPENER V and VERMEULEN LA (2005) A note on the concentrations and bioavailability of selected metals in sediments of Richards Bay Harbour, South Africa. Water SA 31 (4) 589-596. http://www.wrc. org.za/downloads/watersa/2005/Oct-05/1876.pdf

WISLOCKI PG (1989) Environmental aspects of abamectin use in crop protection. In: Cambell WC (ed.) Ivermectin and Abamectin. SpringerVerlag. NY.

WOLFE NL, ZEPP RG, DOSTER JC and HOLLIS RC (1976) Captan hydrolysis. J. Agric. Food. Chem. 24 (5) 1041-1045. 
Available on website http://www.wrc.org.za ISSN 0378-4738 = Water SA Vol. 34 No. 5 October 2008 ISSN 1816-7950 = Water SA (on-line) 